\title{
DETERMINANTS OF BANK PROFITABILITY: A NEW EVIDENCE FROM STATE-OWNED BANKS IN INDONESIA
}

\author{
Ovy Prasanto \\ Dwi Wulandari \\ dwi.wulandari.fe@um.ac.id \\ Bagus Shandy Narmaditya \\ Universitas Negeri Malang \\ Jl. Semarang No.5, Sumbersari, Kec. Lowokwaru, Malang, Jawa Timur 65145 \\ Mahirah Kamaludin \\ Universiti Malaysia Terengganu \\ 21300 Kuala Terengganu, Terengganu, Malaysia
}

received: 11/3/19; revised: 17/7/19; approved: 29/6/20

\begin{abstract}
This paper investigates the factors that determine bank profitability in Indonesia particularly on state-owned banks during the 2007 to 2017. The research applied Vector Error Correction Model (VECM) to measure short-term and long-term effects of independent variable on dependent variable. The research data ini this paper is drawn from two main sources namely Bank Indonesia (BI) and Financial Services Authority (OJK) from 2007 to 2017. The findings showed that in the long term, BOPO, LDR, NPLs, economic growth, and exchange rates have positive relationship toward bank profitability while in the short term, inflation and BI rates do not have effect on bank profitability. However, in the short run, all variables mentioned do not have impact toward banking profitability. In addition, based on Impulse Response Function test, it showed that there are only two independent variables are able to provide a response in case of shock, namely inflation and the exchange rate toward bank's profitability.
\end{abstract}

Keywords: bank profitability; indonesian banks; internal factors; external Factors

\section{INTRODUCTION}

Bank is an institution that has an important role in the economy of a country. Bank is not only act to collect funds from the public but also as an institution that provides funds to the public for various purposes. Indonesia as a developing country has had many growing financial institutions since the financial crisis that occurred in 1998. The existing growth of banking is not only the company's legal status (SOE) but also private-owned. In Indonesia context, the banking system is divided in two which is private bank and state owned bank.

The number of banks in Indonesia during 20102017 showed an increase trend. Meanwhile, the amount of state-owned banks remained stable namely BRI, BNI 46, Bank Mandiri, and Bank Tabungan Negara (BTN). However, in fact, it showed better performance (Haryanto, 2012). Another interesting point of the banking company that becomes the object of research is the high mobility of operational such as collecting funds also tend to increase from year to year level in distributing loans. In Indonesia, the market share of state-owned bank is larger than the other banks (Dewi \& Rahmat, 2016). It remarked that state owned banks have higher efficiency level than other banks from private sector because state owned banks have larger scale.

Banking profitability can be measured using two financial ratios namely Return on assets (ROA) and Return on Equity (ROE). ROE emphasizes to measure the level of profit generated from stocks produced by a company while ROA is more likely to measure the profit from operational activities held by the institution or company either enggaged in the financial field or not. It is important for financial institutions like banks and other financial institutional to increase the level of profitability. As the financial institution, which managed under Indonesian government, the state-owned banks act as the government's partner in holding economic activities such as public financial and microcredit. The banking profitability that measured using ROA during the last ten years from 2007 to 2017 is provided in Figure 1. 
Figure 1 provides information about the growth of ROA during 2007 and 2017 in Indonesia. Overall, the figure shows that the profitability level of banking company in Indonesia has fluctuated during the period. The profitability level of the banking company was less than 3 per cent in the beginning of period, remained stable to the next three months in 2010 then it rose gradually to the level of 3.5 per cent in 2011 and remained stable in the next three years. In that level, banks in Indonesia can be categorized as healthy banks while in the third three months of 2014 until the fourth three months of 2017, the profitability decreased with a fairly healthy category by $1-2$ per cent.

A bank's profitability cannot be separated from external and internal conditions that exist in the company. Internal factors such as the company's management also plays crucial role in generating a higher profit. Meanwhile, macroeconomic conditions arising from the outside of a company also has an important role in influencing the performance of the company. To date, several studies have investigated what factors determine banks profitability in many countries. Staikouras \& Geoffrey (2004) remarked that the profitability and the performance of banks in Europe are not only affected by performance of management but also by the macroeconomic conditions. Further more, the market share in the banking system in Europe has a positive relationship with the structure of the performance of the bank's profitability. The research conducted by Islam \& Nishiyama (2016) found that the existence of liquidity, cost savings on the interest rate structure and economic growth has a negative effect, but inflation has positive influence on bank profitability. Meanwhile, Jaber \& Al-Khawaldeh (2014) emphasizes the profitability of commercial banks in Jordan which is influenced by external and internal factors. The results remarked that internal factors have a significant influence but on capital adequacy and liquidity ratios in the transformation model whilst external factors have a significant relationship either using transformation or not.

A research on banking in Europe conducted by Maurin \& Toivanen (2015) mentioned that external factors affect the outcome of the financial statements at the balance-sheet banking in Europe. However, the balance of capital ratios have a significant impact on banking assets. Rekik \& Mahai (2017) analyzed the profitability of banking in MENA countries. The findings showed that accounting variables are able to explain the price and level of profit efficiency, but the efficiency of the price has a little impact on the profitability of the banking and corporate profits. Besides, it was also found that the bank's profitability and profit efficiency levels have an impact on the financial crisis that occurred in MENA countries. In the other hand, Almazari (2014) conducted research focused on the internal factors that affect the profitability of banks, such as liquidity, credit, investments, capital and risk management of banks. The result shows that TEA, TIA, LQR have significant connection to ROA in Saudi Arabia's banking but there is a negative relationship on banking in Jordan. Hakimi \& Zagdoudi (2017) mentioned that factors which have positive significant impact is economic factors, while inflation has a slightly negative effect in the liquidity ratio for banks in Tunisia while Albuescu (2014) stated that during 2005 to 2013 NPLs has negative impact on bank profitability. Surprisingly, the findings of the previous studies showed various results and there is little attention study on factors affecting banking profitability in Indonesia. Therefore, this paper attempted to examine the factors determine banks' profitability on state owned bank in Indonesia

\section{METHOD}

The research applied a quantitative research using Vector Error Correction Model (VECM) to estimate an empirical phenomenon and analyze the shortterm and long-term causality. VECM can restrict the long-term relationship endogenous variables so that it converges into their cointegrated relation, but still tolerate the existence of the dynamics in the short term. In this study, variable used can be classified as internal variables including LDR and NPL while external variables include economic growth, inflation, $\mathrm{BI}$ rates, and exchange rates. The data were collected from two main resources which is from Bank Indonesia (BI) and the Financial Services Authority (OJK) during 2007 to 2017 . There are several stages in analyzing data includes the stationary test, multivariate cointegration tests, Johansen Cointegration Test, VECM estimation, test statistics T-statistic test, F-statistic test, coefficient of determination (R2), impulse response analysis, variance Decomposition analysis and Granger causality test.

This study uses the Augmented Dickey-Fuller (ADF) to test the stationarity of data. If the value of absolute t-statistic is smaller than the critical value in the MacKinnon table at various levels of confidence $(1 \%, 5 \%$, and $10 \%)$, it indicates data is not stationary. Besides that, it can also be seen in the value of prob greater than 0.05 which also indicates that the data is not stationary. Conversely, if the ADF value is greater than the critical value of various confidence levels $(1 \%$, $5 \%$, and $10 \%$ ), then there is no unit root or stationary data. The ADF was formed in order to obtain the autoregressive equation as follows:

$$
\begin{aligned}
& D X_{t}=a_{0}+a_{1} T+a_{2} X_{t-1}+b_{1} D X_{t-1}+b_{2} D X_{t-2} \ldots b_{t-1} D X_{t-1}+U_{t} \ldots \\
& \text { or } \\
& D X_{t}=a_{0}+a_{1} T+a_{2} X_{t-1}+b_{1} \sum_{i=1}^{m} D X_{1-t}+U_{t} \ldots \ldots \ldots \ldots . . .
\end{aligned}
$$

VAR estimation is very sensitive to lag length used. If the lag in judicial stationarity too small, then the residuals of the regression unable to show the process 
of white noise so that the models can not accurately estimate the actual error. As a result of mistakes, standards are not estimated. However, if the lag is incorporated too much, it will reduce the ability to reject $\mathrm{H} 0$ as additional parameters that too much will reduce the degree of freedom. The testing lag also has the benefit of eliminating the autocorrelation problem, therefore, the use of optimal autocorrelation lag problem is no longer expected to arise.

The existence of non-stationary variables can cause the most likely long-term relationship between the variables. Hence, cointegration test is required. Cointegration test is a test aimed at finding long-term and short-term between variables. In this study, Johansen cointegration tests used in the test for the existence of cointegration between the variables. The test developed by Johansen can be used to determine the cointegration number of variables (vectors). Johansen test can be seen with the autoregressive models as follows:

$\Delta \mathrm{y}_{\mathrm{t}}=\Pi_{\mathrm{t}-1}+\sum_{\mathrm{i}=1}^{\mathrm{p}-1} \Pi_{\mathrm{t}} \Delta \mathrm{y}_{\mathrm{t}-1}+\mathrm{B} \pi_{\mathrm{t}}+\varepsilon_{\mathrm{t}}$

$\Pi=\sum_{\mathrm{i}=1}^{\mathrm{p}_{\mathrm{i}}} \mathrm{A}_{\mathrm{i}}-\mathrm{I}, \Pi_{\mathrm{i}}=-\sum_{\mathrm{j}=\mathrm{i}+1} \mathrm{~A}_{\mathrm{j}}$

Granger Causality Test aims to determine the causal relationships between variables used in the study. The effect of causation is addressed to see the effect of each variable against another one by one instead of per group.

VECM models can be applied if the studied variables proved to have a cointegration relationship. If the cointegration test results indicate a long-term equilibrium relationship, the results of the relevant dynamic regression estimation are VECM models. It can be used as a method to determine the effect of the caused by a variable in the long term and short term. VECM can be formulated as follows:

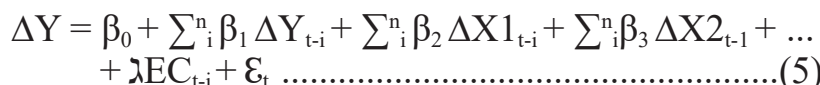

\section{RESULTS}

Cointegration test aims to understand whether the regression residuals have reached stationary or not. According to Rosadi (2012), the cointegration testing can be done using two methods namely Engle Granger test and Johansen cointegration test. Johannsen cointegration test is more focused on whether there is a long-term influence in the existing variables in the study. Based on the Johansen cointegration test, we can withdrawn a conclusion that if the value of the Maximum Eign value Trace and statistics is greater than the value of the appropriate critical values, then we can analyze the data using analytical Vector Error Correction Model (VECM). In other hand, if the value of statistics Trcae and Maximum Eignvalue is smaller, then the proper analysis method is using Vector Auto Regresive (VAR).
Based on the cointegration tests in Table 1, it can be seen that the value Trace Statistic is higher than Critical Value. It means that the variables used in this research have a long-term relationship. There are two vectors that have a trace statistic value $>$ critical value, it is the trace statistic 216.4393 to 159.5297 critical value and probability value of 0.0000 . Additionally, there is one vector that has a value of trace statistic $143.5009,125.6154$ critical value with probability level of 0.0026 . Variables used in this research method have co integration between trace test and max eigen trace test at a rate of 95 per cent. It can be concluded that there is a long-term relationship between the variables in this study, so that between these variables can establish a linear relationship.

VECM test provides the information the longterm and short term relationship between variable (Table 2). This study has 40 observations and 8 variables. In the optimal lag test, the data used in this study demonstrates the optimum level on the lag-3, therefore, from estimation of VECM, it can be known the comparison of the t-statistics lag-3 with t-table. If the $t$-statistic $>t$-table variables used have a long-term or short-term relationship. The long-term relationship between independent variables and dependent variable can be seen from a comparison of the value of t-statistic of each independent variable including ROA, LDR, NPLs, Economic Growth, Inflation and BI Rate.

From the estimated VECM, it showed that in the long-term, variables that have a direct impact on banking company's profitability is LDR, NPL, economic growth, and exchange rates. Further result, in the longterm, Inflation and BI rates have a significant negative effect while in the short term, there is no variables that have an influence on banking profitability. Therefore, it indicates that the data generated from each of the variables in the volatile conditions need adjustments to the existing economic conditions. Besides, based on the calculations of Impulse Response Function, each variable all of stands at under zero so that the shock caused by the independent variable has no effect on the changes brought about by ROA or banking profitability of state owned bank during 2007 to 2017. Judging from the calculation of Variance Decomposition of each individual independent variable, they are able to explain the shock that occurred from the 3 rd period. There are only two were which able to explain a significant relationship namely BI rates and inflation. Both of these variables can explain the relationship turmoil on banks' profitability.

BI rates have been able to explain the relationship in the second period with the value of 3.370 per cent. After that, in the third period, it had decreased to level of 1.482 per cent. In the next period, it continued to rise gradually until reached about 4.214 per cent in the tenth period. It can be concluded that BI rates significantly explain the relationship turmoil on the ROA's dependent 
variable. The same thing happens with inflation, the relation can be explained on the second period with a value of 0.007 per cent. In the next period, it continued to rose gradually from the third period to the tenth period. In the tenth period, the grade is about 0.958 per cent and in the ninth period is 0.953 per cent. Therefore, it can be concluded that inflation is able to explain the turmoil relationship that occurs in ROA.

The number of operational costs will also be related to the operating income to be acquired. In this study, BOPO does not impact or shock ROA, it means that when there is an increase or decrease in the percentage of BOPO, then the magnitude of the bank's profitability also remain unchanged. This is reflected in the impulse response function of the ROA toward BOPO. This finding in contrast with previous study by Peling \& Sedana (2018) which mentioned that BOPO has a negative impact on ROA. It is reasonable because when a bank gains profit or a relatively high income and they are able to reduce operating costs as low as possible, this condition will be followed by the raise of ROA ratio. However this finding agree with previous study by Yusriani, Mus, \& Chalid (2018) which showed that BOPO has positive and a significant impact on profitability. Then, it indicates that when BOPO increase, it will be followed also by the increase of ROA or banking profitability concerned. The banks must be able to set the conditions when their liquidity exceeds its limit, it is intended to load or operating costs does not lower the level of profitability that is owned by a banking company.

Loan to Deposit Ratio (LDR) is a ratio that describes a level of total loans owned by banks with the overall amount of funds as well as its own capital. The result of the study shows that LDR has a long-term and positively influence banking profitability (ROA) while in the short term, it has no influence on bank profitability. Thus, from the results, it can seen that 1 per cent increase in the LDR will be followed by a 1 per cent increase in ROA. However, it is only applicable in the long-term liability of a banking enterprise, while the increase or decrease in the short-term which happened on the LDR would has no meaning and influence in return on assets or profitability.

\section{DISCUSSION}

This finding is different to the research conducted by Yudha et al. (2017) which explained that LDR has a negative and insignificant impact. This finding is not relevant with the existing theory. According to the economic theory, when a bank distributes their credit using the third parties fund owned by the bank, they will get a maximum profitability from the lending of funds. It will be valid in the long term because a company will be able manage theirown company well and be able to adapt to changes in the existing economy. According to Hossain \& Khalid (2018), LDR has positive relation to the amount of bank profitability that are examined, but they also have a significant negative impact on the dependent variable that isused. Therefore, the results of the research conducted by the researcher in the thesis, it is found that in the long term, LDR has a positive and significant impact on profitability (ROA). In another study, it is not explained in detail whether there is influence in the short term or in the long term.

The result showed that NPL has a significant positive effect in the long term to bank profitability. In the short term, NPL does not have an influence on the value of bank profitability. It can be seen from the result that in the long term, the magnitude of the NPL ratio may affect the amount of profitability generated by the company's existing conventional banking in Indonesia from 2007 to 2017.

Kalioglu et al. (2017) explained that the number of non-performing loans (NPL) have a significant influence on the amount of the related bank profitability. Does not depart from the policies adopted by the banks themselves and government regulation on soft loans should be controlled so that the amount of the high NPL does not burden the bank concerned. Meanwhile, according to Ozurumba (2016), NPL has a negative influence on the number of the existing banking profitability. It is based on the fact that NPL only acts as a ratio that will affect the health of the bank, not on profitability. The various views of this mattter indicates that NPL is not only considered as a component in the health of banks but NPLs also have an impact on the profitability amount of a bank based on the study.

According Murgas \& Bohm (2014), one effect arising from good economic growth is the quality of life, it has a positive correlation with changes in the circumstances of each individual. Under these conditions, in the long run people will know better about banks so that they will utilize banking facilities well so that it will increase the profitability of the banks concerned. According to research conducted by Klein \& Weill (2018), it is mentioned that high banking profitability will have an influence on the amount of economic growth in a country. This finding also remarked indifference result previous study by Suteja \& Ginting (2014) which mentioned that GDP affects on ROA. It is also in line with when the economic growth that rise gradually it will also increase the income received by the public, they will tend to put a high usability as well as be aware of banks in their lives. In the long run an economy will encourage more economic activity either in the banking sector or the other. As disclosed by Tan \& Floros (2017) high economic growth there can also reduce the level of banking profitability. 
Based on findings of this study, it shows that in the long term as well as long-term inflation does not have a significant and negative influence on the amount of ROA. Therefore, the high and low level prevailing price has no effect on the level of the conventional banking peresoran profitability owned by state owned banks in Indonesia. Inflation is not yet able to explain the effect on the profitability of the existing banking in Indonesia. Inflation only has a little effect on the existing operational and credit risk provided by the bank concerned. Thus, banks should anticipate the things that can happen in the future, especially Indonesia as a country that adheres to open economic system, inflation will continue to grow while the bank as a financial institution which has a major role in carrying out economic activities need to have a good operational system to mitigate the impact of inflation.

In managing inflation, Bank Indonesia issued BI rates as the reference rate for general banking operations in Indonesia. Based on the test results and research that has been made, it is known that the amount of BI rate has no significant effect on profitability (ROA) of the banking company in Indonesia. It can be said that the benchmark interest rate which is used to increase lending and deposit rates at Bank do not have any impact on banking profitability generated by the company.

According to Alim (2014), the amount of the existing $\mathrm{BI}$ rates is only able to explain a little percentage of the profitability of the existing bank. Besides, Aliviani et al. (2015) explains that BI rate also has no significant effect on the size of bank profitability. Further, BI rate is only capable of being a benchmark interest rate that has not yet affected the level of profitability of the existing banking. However, banks as the central financial institution should not be ignored because it is unconsciously. BI has a role in the financial industry in Indonesia especially bankings.

Based on the results of data test using VECM, it is known that in the long term, the value of rupiah against the dollar in each three months has a positive and significant effect, while in the short term it is the opposite. Therefore, it can be seen that exchange rate plays an important contribution the company's level of profitability of banking in Indonesia from 2007 to 2017, although in this period the exchange rate of rupiah to dollar experiencing ups and downs. Hasanov et al. (2018) mentions that the large capacity of the economy, including the exchange rate may have an influence on the amount of existing banking profitability. So it can be said that trading activity using foreign currency such as dollar has a role in improving the existing banking profitability, especially in the banking company's ROA. On the other hand, the company banking have a broad scope in their activities both domestically orinternationally, so it is not strange that in long term, the exchange rate has a positive and significant influence.

\section{CONCLUSION}

This study has discussed factors determining banks' profitability in Indonesia. The result of this study indicates that BOPO, LDR, NPLs, Economic Growth, and Exchange rates significantly impact on banks' profitability of state owned banks in Indonesia whereas BI rates and inflation do not have influence on banking profitability. In the short term, BOPO, LDR, NPLs, economic growth, inflation, BI rate, exchange rates do not affect to profitability (ROA) in the banking company in Indonesia. The shock of the BOPO, LDR, NPLs, economic growth, inflation, BI rate, exchange rate also do not have influence on the ROA. As banks owned by the government, banking company should be able to withstand the shocks of both internal and external sides. This is conducted because in the future, in an era of increasingly force global competition, the macroeconomic conditions will fluctuate as well as the need to improve the quality of human resources owned by the company.

\section{REFERENCES}

Alim, S. 2014. Analisis Pengaruh Inflasi dan BI rate terhadap return on assets (ROA) Bank Syariah di Indonesia. Jurnal Ekonomi Modernisasi, 10(3), 201-220.

Aliviani, A., Siregar, H., Maulana, N. T. A., \& Hasanah, H. 2015. The Impact of Macroeconomic Condition of the Bank's Performance in Indonesia. Bulletin of Monetary, Economics and Banking, 17(4), 391-414.

Almazari, A. A. 2014. Impact of Internal Factors on Bank Profitability: Comparative Study between Saudi Arabia and Jordan. Journal of Applied Finance \& Banking, 4(1), 125-140.

Haryanto, S. 2012. Kinerja dan Efisiensi Bank Pemerintah (BUMN) dan BUSN yang Go Public di Indonesia. Modernisasi, 8(2), 165-179.

Hakimi, A., \& Zaghdoudi, K. 2017. Liquidity Risk and Bank Performance: An Empirical Test For Tunisian Banks. Business and Economic Research, 7(1), 46-57.

Hasanov, F., Mammadov, F., \& Al-Musehel, N. 2018. The Effects of Fiscal Policy on Non-Oil Economic Growth. Economies, 6(27).

Hossain, A., \& Khalid, M. S. 2018. Determinants of Bank Profitability Before and During Crisis: Evidence From Bangladesh. International Journal of Finance and Accounting, 7(5), 142-146.

Islam, M. S., \& Nishiyama, S. 2016. The Determinants of Bank Profitability: Dynamic Panel Evidence from South Asian Countries. Journal of Applied Finance \& Banking, 6(3), 77-97.

Jaber, J. J., \& Al-Khawaldeh, A. A. 2014. The Impact of Internal and External Factors on Commercial Bank Profitability in Jordan. International Journal 
of Business and Management, 9(4), 22-30.

Kalioglu, E., Telceken, N., \& Ocal, N. 2017. Effect of Asset Quality on the Bank Profitability. International Journal of Economics and Finance, 9(7), 60-68.

Klein, P., \& Weill, L. 2018. Bank profitability and economic growth. BOFIT Discussion Papers 15/2018, Bank of Finland, Institute for Economies in Transition.

Maurin, L., \& Toivanen, M. 2015. Risk, Capital Buffers and Bank Lending: The Adjusment of Euro area Banks. Journal of Banking and Financial Economics, 1(3), 113-129.

Murgas, F., \& Bohm, H. 2014. Does Economic Growth Improve Quality of Life?.15th International Multidisciplinary Scientific Geo Conference SGEM 2015. Ecology, Economics, Education and Legislation. Conference Proceedings, 3, 213-220.

Ozurumba, B. A. 2016. Impact of Non-Perfoming Loans on the Performance of Selected Commercial Banks in Nigeria. Research Journal of Finance and Accounting, 7(16), 95-109.

Peling, I. A. A., \& Sedana, I. B. P. 2018. Pengaruh LDR, NPL dan BOPO terhadap Profitabilitas Pada PT. BPD Bali Periode Tahun 2009-2016. E-Jurnal
Manajemen Universitas Udayana, 7(6), 2999-3026. Rekik, M., \& Mahai, K. 2017. Determninants of Banks' Profitability and Efficiency: Empirical Evidence from a Sample of Banking Systems. Journal of Banking and Financial Economics, 1(9), 5-23.

Suteja, J., \& Ginting. 2014. Determinan Profitabilitas Bank: Suatu Studi Pada Bank yang Terdaftar di BEI. Trikonomika, 13(1), 62-77.

Staikouras, C., \& Wood, G. E. 2004. The Determinants of European Bank Profitability. International Journal of Economics and Business Research 3(6), 57-68.

Tan, A. Y., \& Floros, C. 2012. Bank Profitability and GDP growth in China: A Note. Journal of Chinese Economics and Business, 10(3), 267-273.

Yudha, A., Chabachib, M., \& Pangestuti, I. R. D. 2017. Analysis of The Effect of NPL, NIM, Non Interest Income, and LDR Toard ROA with size as Control Variables (Differences Study on Domestic and Foreign Banks Listed on BEI Period 2010-2015). Jurnal Bisnis STRATEGI, 26(2), 100-113.

Yusriani., Mus, A. R., \& Chalid, L. 2018. Pengaruh CAR, NPL, BOPO dan LDR terhadap Profitbailitas pada Bank Umum Milik Negara Persero di Bursa Efek Indonesia. Jurnal Riset Edisi XXV, 4(2), 1-17.

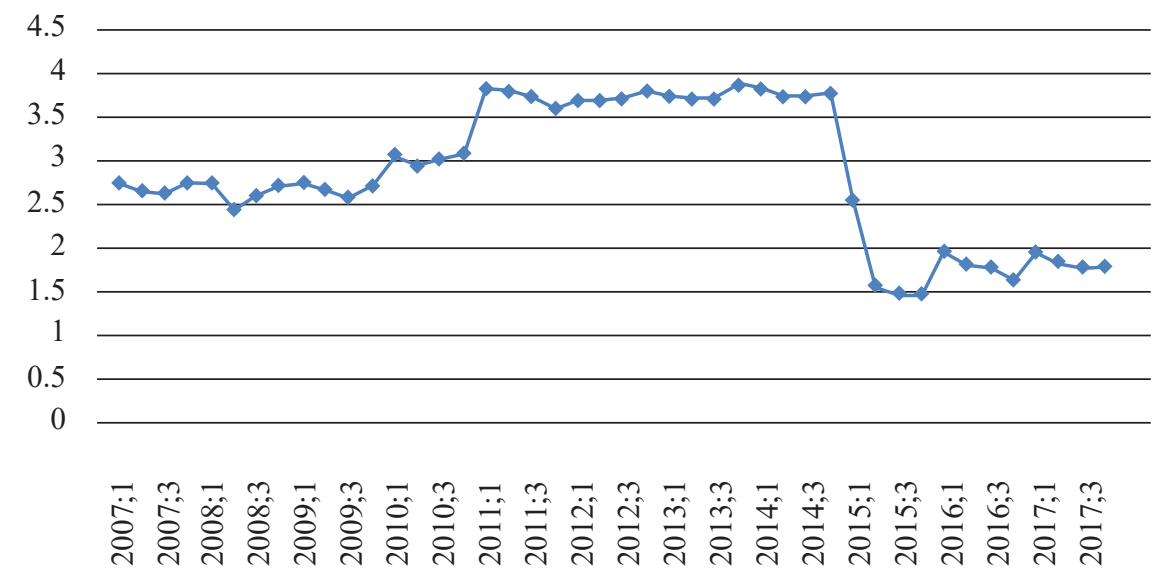

Source: OJK (2018)

Figure 1. The trend of ROA state owned banks during the 2007-2017 
Table 1. Johansen Cointegration Test Results

\begin{tabular}{|c|c|c|c|c|}
\hline Hypothesized & & Trace & 0.05 & \\
\hline No. of CE (s) & Eigenvalue & statistics & critical Value & Prob. $* *$ \\
\hline none * & 0.823887 & 216.4393 & 159.5297 & 0.0000 \\
\hline At most $1 *$ & 0.699045 & 143.5009 & 125.6154 & 0.0026 \\
\hline At most 2 & 0.592848 & 93.067567 & 95.75366 & 0.0755 \\
\hline At most 3 & 0.376949 & 55.32772 & 69.818889 & 0.4054 \\
\hline At most 4 & 0.304843 & 35.45639 & 47.85613 & 0.4241 \\
\hline At most 5 & 0.244025 & 20.18443 & 29.79707 & 0.4104 \\
\hline At most 6 & 0.143713 & 8.435051 & 15.49471 & 0.4201 \\
\hline At most 7 & 0.04465657 & 1.918748 & 3.841466 & 0.1660 \\
\hline
\end{tabular}

Trace test indicates 2 cointegrating eqn (s) at the 0:05 level

* Denotes rejection of the hypothesis at the 0:05 level

** MacKinnon-Haug-Michelis (1999) p-values

Unrestricted Cointegration Rank Test (Maximum Eigenvalue)

\begin{tabular}{lcccc}
\hline \multicolumn{1}{c}{ Hypothesized } & \multicolumn{3}{c}{ Max-Eigen } & $0: 05$ \\
\hline No. of CE (s) & Eigenvalue & statistics & critical Value & Prob. ** \\
\hline none * & 0.823887 & 72.93838 & 52.36261 & 0.0001 \\
At most 1 * & 0.699045 & 50.43336 & 46.23142 & 0.0168 \\
At most 2 & 0.592848 & 37.73985 & 40.07757 & 0.0896 \\
At most 3 & 0.376949 & 19.87133 & 33.87687 & 0.7655 \\
At most 4 & 0.304843 & 15.27196 & 27.58434 & 0.7264 \\
At most 5 & 0.244025 & 11.74938 & 21.13162 & 0.5726 \\
At most 6 & 0.143713 & 6.516303 & 14.26460 & 0.5479 \\
At most 7 & 0.044657 & 1.918748 & 3.841466 & 0.1660 \\
\hline \multicolumn{5}{l}{ Max-eigenvalue test indicates 2 cointegrating eqn (s) at the 0:05 level } \\
* Denotes rejection of the hypothesis at the 0:05 level \\
** MacKinnon-Haug-Michelis (1999) p-values
\end{tabular}

Source: The data were processed using Eviews 9.0

Table 2. Estimate of VECM

\begin{tabular}{ccccccccc}
\hline Var & ROA (Y) & BOPO (X1) & LDR (X2) & NPL (X3) & PERT (X4) & infl (X5) & BEER (X6) & EXCHANGE RATEs (X7) \\
\hline \multicolumn{7}{c}{ Long-term } \\
\hline & 1.000000 & 2.866052 & 3.054956 & 0.845033 & 4.145807 & -0.101208 & -0.634429 & 4.652774 \\
& & {$[3.80858]$} & {$[1.80930]$} & {$[1.80417]$} & {$[9.07834]$} & {$[-1.14290]$} & {$[-1.00714]$} & {$[4.27643]$} \\
\hline \multicolumn{7}{c}{ Short-term } \\
\hline$(-1)$ & 0.293585 & 0.017178 & 0.015728 & -0.427150 & 0.185022 & 1.393658 & -0.050603 & -0.127501 \\
& {$[1.60614]$} & {$[0.19737]$} & {$[0.17242]$} & {$[-1.17939]$} & {$[1.51670]$} & {$[0.59205]$} & {$[-0.043463]$} & {$[-1.57232]$} \\
\hline
\end{tabular}

Source: Data processed by Eviews 9.0 